\title{
CHINDIA THE TITANS' CHANGE HAS COME
}

\author{
Luca DIACONESCU * \\ University of Craiova, Doctoral School of Sciences, Field of Geography, 13st, Alexandru Ioan Cuza \\ St., 200585, Craiova, Romania, e-mail: diaconesculuca@yahoo.ro \\ Mirela Elena MAZILU \\ University of Craiova, Doctoral School of Sciences, Field of Geography, 13st, Alexandru Ioan Cuza \\ St., 200585, Craiova, Romania, e-mail: mirelamazilu2004@yahoo.com
}

Citation: Diaconescu, L., \& Mazilu, M.E. (2021). Chindia the Titans' Change Has Come. Revista Română de Geografie Politică, 23(1), 29-46. https://doi.org/10.30892/rrgp.231104-347

\begin{abstract}
Indian and Chinese civilizations have economically dominated the world for 15 centuries, when they are overtaken by: Europe, America, Russia, the Arab states, Brazil, Mexico or Japan, shamefully entering a shadow cone that stretched 3-4 centuries. Towards the end of the twentieth century they begin to matter again, and during the twenty-first century it seems that they will replace the European Union and the United States, dividing the planet into two major spheres of influence, avoiding regionalization on religious or civilizational criteria or the multipolar world predicted by some geopolitics, so China will represent the continuity of the planned and agile economy of the USSR, but with a high dose of determination found locally in the Japanese and Koreans, while India will be the 3rd West after the end of world domination by Western Europe and the USA, based on democracy, parliament, federalism and the individual economy but also characteristics specific to the states of the planetary geopolitical south.
\end{abstract}

Key words: Asia centuri, China and India, great civilizations, competition, world mega-powers

\section{INTRODUCTION}

After 1500, European economic powers developed more and more by seizing colonies or semi-colonies around the globe, directly owning about $90 \%$ of the Earth's territory (considering the Tsarist and Ottoman empires as semi-European powers), even if their population reached to only $19 \%$ of the world's population in $1500,21 \%$ in 1700 and $28 \%$ in 1900 , when they reach the peak that triggers the two great world wars. Slowly, as the United States gains independence following European success, Russia (USSR) is also gaining power, but also small territorially or sparsely populated countries such as: Japan, Canada, Mexico or Australia that are becoming economic giants, and rising oil prices, trade, finance, basement resources or key strategic positions other global actors between regional powers or 
in the top of the world's economies such as: Saudi Arabia, United Arab Emirates, Venezuela, Argentina, South Africa, Iran, Turkey, Switzerland, Norway, Singapore, Thailand, Taiwan or South Korea. During this time, Chindia (India and China) which hold continental territories and generally over 33\% of the world's population (40\% in 1900), seem to no longer matter, getting worse and worse, being colonies, semi-colonies, facing with natural disasters, famines, economic isolation and the most severe dictatorships, their citizens being in a continuous battle against each other when they know endless civil wars. The historical explanations for such an anomaly are difficult to give, there are so many lacking, isolated, mountainous states, also at war, with populations that did not even exceed the population of cities in the top 5 urban areas of China or India, all these having miraculous economic successes. Similar to the comparison between the piranha and the whale, small, very economically aggressive states were tirelessly attacking the financial market to round out profits while the world's heavyweights, India and China, seemed to not wake up.

But the miracle of China finally appears at the end of the $20^{\text {th }}$ century, and the monetary bank created by it: the Asian Infrastructure Investment Bank (AIIB), established between 2013 and 2016 based in Beijing, has already co-opted Western European states, recognizing his superiority after so many centuries (McGregor, 2017; Khanna, 2019). India in turn, starting more clumsy, attracts itself in competition with China: the USA, Great Britain, Australia and Japan, which will become their submissive masters in no more than two or four decades (Ayres, 2017). The BRICs set up in 2009 together with: Russia, Brazil and South Africa represented the first concrete step of world enlargement, and the current Himalayan conflict that attracted on the side China: Europe, Russia and Pakistan, and from India: Japan, USA, Australia and Vietnam was the start of the $21^{\text {st }}$ century competition to replace the old US and European powers with the new powers China and India, which will divide their Earth, with the $36 \%$ of the world's population today, into two large spheres of economic and military influence.

\section{GREAT CIVILIZATIONS, GREAT COLONIES}

India with the Indus Valley and China with the Yellow River Valley were among the first three planetary mega-civilizations along with the Fertile Crescent (Nile, Mesopotamia and Levant), more than 4,000 years ago. In India, the 4,500year-old cities of Mohenjo Daro and 5,000-year-old Harappa dictated the shape of the world's first great cities, and China had the world's first border 2,500 years ago when construction began on the Great Wall of China. Later, after $200 \mathrm{BC}$, it seems that the Silk Road that connected Europe to China became the main land axis of the world and the rise of ancient Greece was possible apparently with teachings from India. When the Arab Empire rose in the Middle East after 600 and in the North Africa after 700, it blocked access to the great powers of Genoa and Venice, which cut their status as European leaders due to the Indian spice trade, and after 1300 The Ottoman was a new stop.

Once this route was blocked, it forced Europeans to find alternative routes, the search for sea routes to India being the reason why Spain and Portugal, later followed by the Netherlands, France and Great Britain, left Europe, laying the foundations of European empires. It was the sea routes to India and the liberation of the land route between the Mediterranean and India through the English conquest of the Arabs and Persians that made possible the colonization of the whole of India, which became the English crown and the 
main conquest for the whole of Europe. Even though it represents just over 3\% of the world's surface area and $16 \%$ of the English Empire, the Indian Subcontinent had $78 \%$ of its population in 1900, with 300 million people out of 385 totaling the empire, making England the largest power from world that far exceeded the French Empire.

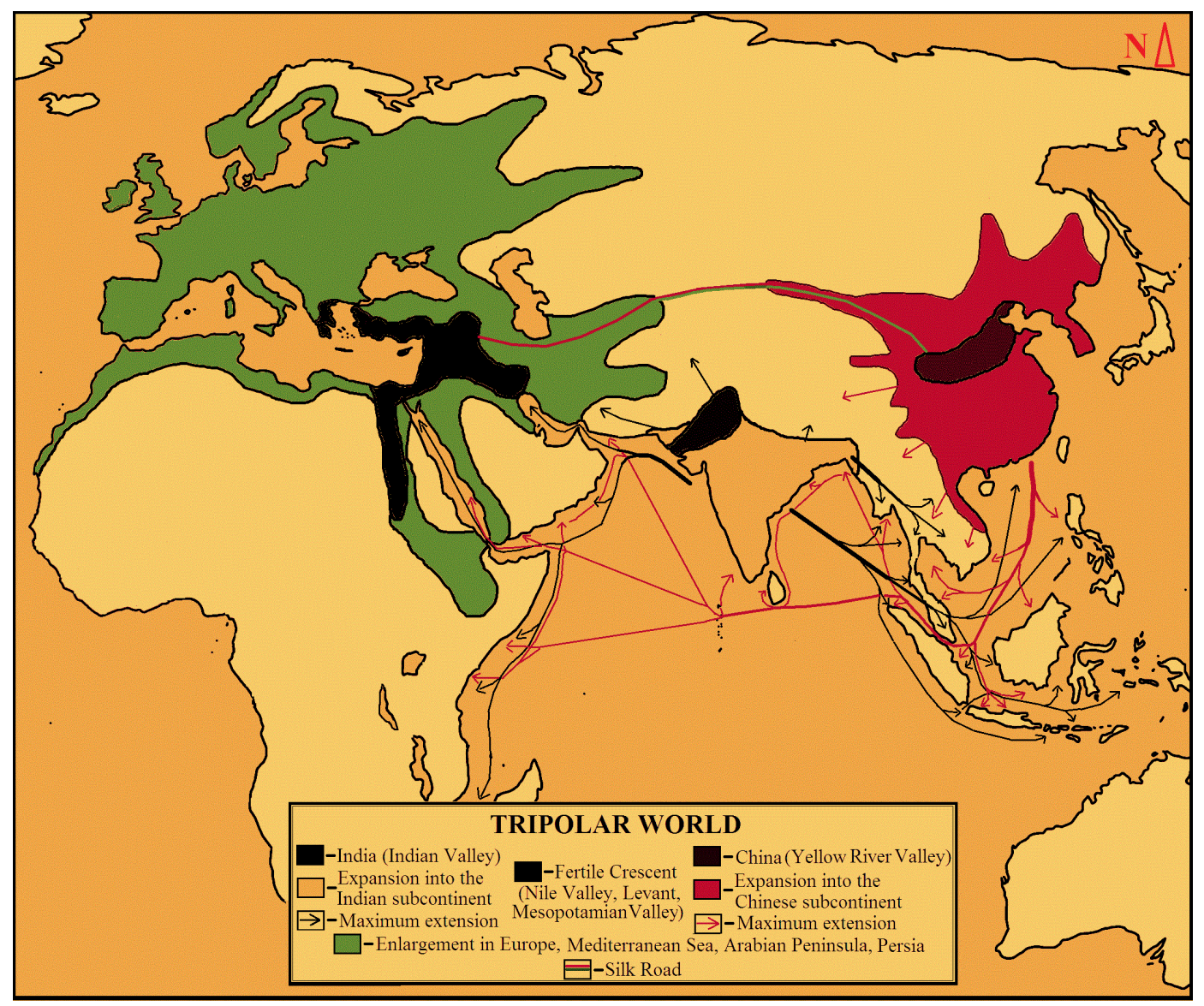

Figure 1. The tripolar division of the known world, between civilizations: Fertile Crescent, India and China, between $3000 \mathrm{BC}$ and $500 \mathrm{AD}$ Sources: processed by: Attili, 2016; Mâșu, 2014

Also, the existence of the Himalayan mountains that blocked land access to China, but also the development of the Russian Empire that stretched south to the Silk Road, made Europeans only semi-colonize China in the absence of direct access to it, even if weapons with with the help of which they became masters were due to gunpowder, the orientation of navigation on the seas and oceans was done with the help of the compass, and maps and writing were printed on paper, all of which appeared in China and sent on the Silk Road to Europe, with several centuries ago (Hobson, 2004; Marshall, 2019; Kaplan, 2015).

And under these conditions, in 1700 all of India and China were the dominant world powers to the detriment of all Western European empires taken together. After the conquest of India by the British, it was not until 1800 and 1850 that Western Europe surpassed India and China economically, and the United 
States surpassed the two around 1900, not only because of the economic rise of the last two, and because India and China were declining economic. Western Europe begins the conquest of India after 1498 and ends after 1700, but after a sudden economic growth they reach the beginning of the Second World War to finally hold $25 \%$ of the world's economic power (similar to India before 1700 , and over $32 \%$ of China's world economic power in 1820 before its decline, Western Europe only managed to equalize in 1900, and the United States has never had so much power). We could consider that it was the decline of India and China that led to the economic rise of Europe and later of the USA, making room for the two new economic poles.

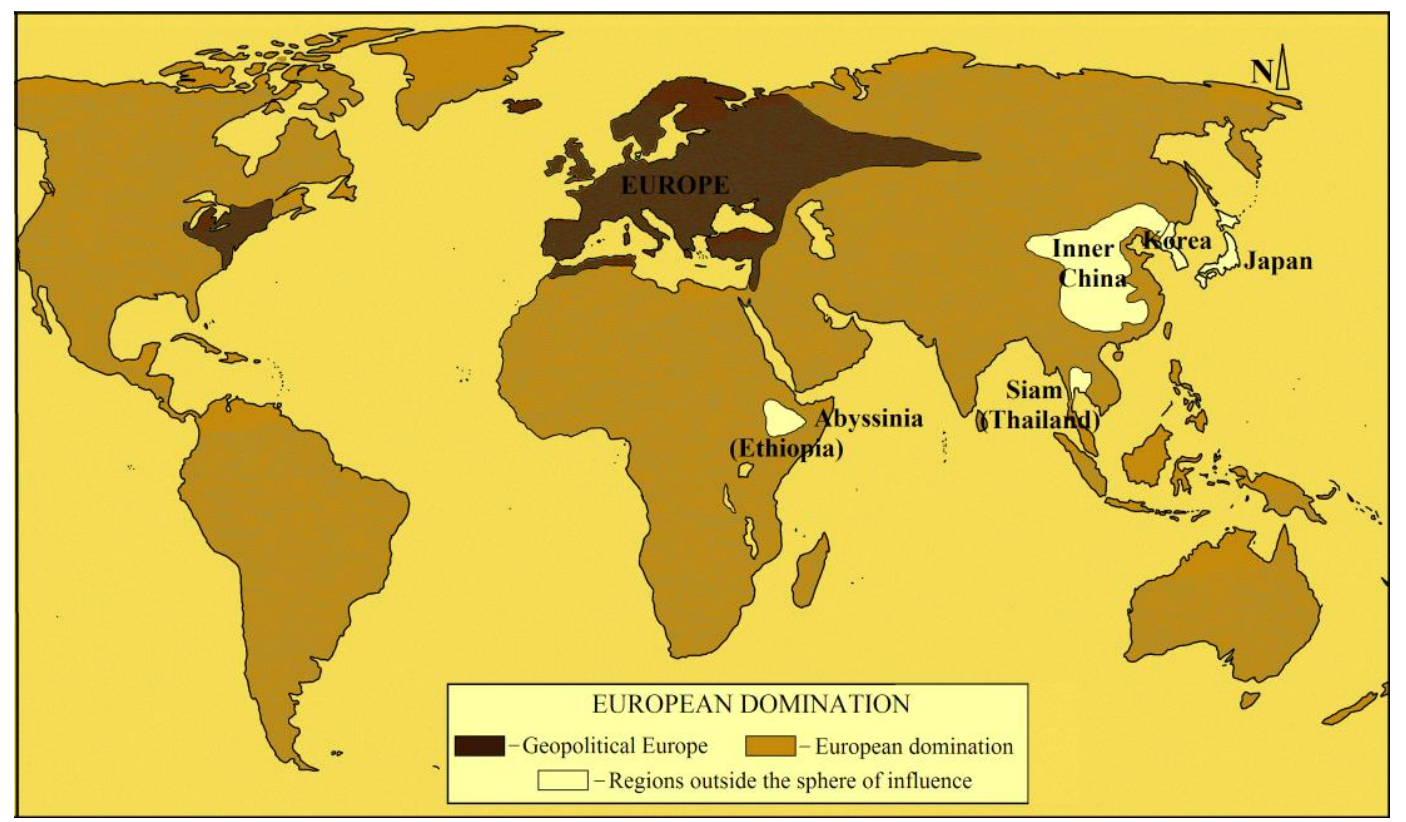

Figure 2. The unipolar world dominated by Europe, between 1800 and 1940

Sources: processed by: Baten, 2016; Roberts, 2013; Herman and Grama, 2018; Parthasarathi, 2011

\section{GEOGRAPHY AFTER INDEPENDENCE}

The Indian subcontinent gained independence from the British Empire in 1947, owning a productive agricultural area, with 2.1 million $\mathrm{km}^{2}$ of arable land (double the European Union of only 1 million $\mathrm{km} 2$ ) and extensive access to the ocean being economically advantageous, but its total appearance in the southern half of the planet's land did not offer great economic chances, and only former European colonies with serious economic problems had access to the Indian Ocean (Ianoș and Iacob, 1989; Gâștescu et al., 2004). Also, the presence of the Himalayan mountains in the north, the jungle in Myanmar and the desert occupied by Muslim populations in the west have forced it to be a maritime power par excellence. Its entire territory of 5 million $\mathrm{km}^{2}$ has been divided, leaving India with only 3.2 million $\mathrm{km}^{2}$ (1.7 million $\mathrm{km}^{2}$ of arable land, being the first in the world), the rest being torn from its territory on the surface of which they have appeared: Nepal and Bhutan (Buddhist India), the islands of Sri Lanka and Maldives which represented a kind of: Malta, Gibraltar, Hong Kong or Singapore for the English (this being island India) and Pakistan (i.e. Islamist India), which 
included East Pakistan (present-day Bangladesh) and West Pakistan (present-day Pakistan), which practically occupies the ancient Indian civilization of the Indus Valley, with Hindu India taking its history. This marginal territory, composed of 6 states surrounding Hindu India, comprises $38 \%$ of the entire territory of the Indian Subcontinent and $25 \%$ of its population, with over 440 million people (owned by: USA, UK and Canada combined), being the second largest economic, national, historical and geopolitical disaster in India (after the conquest of the territory by the British and its transformation into a colony, after 1700).

Instead, China, which has become communist, loses few territories that would rightfully belong to it, consisting of: Macao (Portuguese), Hong Kong (English) and Taiwan (pro-Japanese and American), instead taking over Manchuria (a semi-Chinese territory, similar to Pakistan for India), Inner Mongolia (remaining independent of just over half of Mongolia's legal territory, with its current capital at Ulan Bator), Tibet (previously administered by British-based Indians) and Uyghur or East Turkestan (part of the current Central Asian states and linguistically related to Turkey) (Popa, 2004; Goh, 2016; Navarro, 2011; Stuart-Fox, 2003; Roy, 2001). Thus, the Chinese territory of 3.2 million $\mathrm{km}^{2}$ (similar to India) which comprises over $85 \%$ of the country's population, has another 6 million $\mathrm{km}^{2}$, growing China today to continental dimensions where almost $60 \%$ of the area has a questionable Chinese origin. Arable land by 0.9 million $\mathrm{km}^{2}$ (lower than in India and ranked 4th in the world after: India, USA and Russia and equal to the European Union) is restricted on the coast (plus 0.2 million $\mathrm{km}^{2}$ finds the $60 \%$ of the rest of the territory) in the east, which along with natural impediments in the west such as the Himalayas and the Gobi Desert, frozen Siberia in the north and the southern jungle of the Indochina Peninsula, should make China a maritime power. But the expansion of enemy states along the coast near its coasts (Taiwan, Japan and Vietnam, eventually becoming US allies), limits China and forces it to be a continental power. This explains the current affinities between China and: Russia, Pakistan, Myanmar or Kazakhstan, being in a similar situation to: Germany, Russia, Italy or Turkey, being able to choose whether to become a land or sea power, both options being drastically limiting.

\section{ABOLITION CIVILIZATIONS AND RETURN FROM THE LAST ONE CENTURY}

India became a colony of European powers, ruling over some of its territories: Portugal, the Netherlands and France, eventually the British conquering the entire territory and erasing from the face of the earth a millennial state (similar to the disappearance of ancient Greece after Persian, Roman and eventually Ottoman invasions, or how millennial Egypt disappeared under the rule of the Arabs, Ottomans and English). Instead, China was a semi-colony and its entire exit to the world market was directed from the outside, somewhat resembling Persia, ruled in the north by the Russians and in the south by the British.

After the two great world conflagrations of the early twentieth century, when European empires soaked in power massacred each other, India finally gained independence, but civil wars and the division of the country did not give it any chance to develop, remaining an area of famine for many years (until independence, under the British mandate more than 60 million people died of starvation, following a rapid decline in this cause among the dead, after independence, another more than 4 million lost in the war Indian-Pakistani and Bangladesh independence) (Roberts, 2009; Huntington, 2018). China, which in turn became independent under the communist regime, experienced some of the 
worst political decisions in history, through the Great Leap Forward measures, in which 40 million people died of starvation.

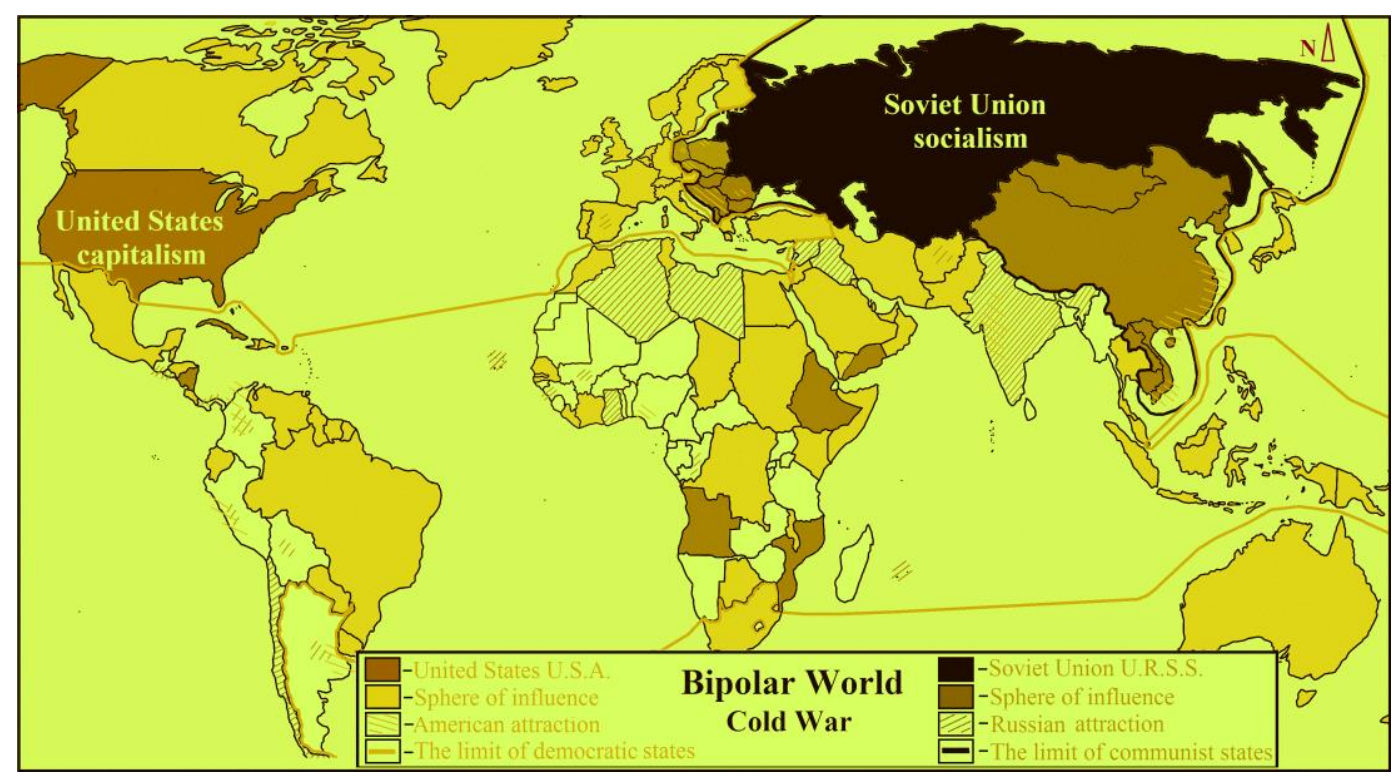

Figure 3. The Bipolar World and the Cold War. The spheres of attraction of the USA and the USSR, between 1945 and 1990

Sources: processed by: Ilieș, 2006; Gray, 1977; Săgeată, 2008; Grumaz, 2013; Toffler \& Toffler, 1995

US investment in allies from the vicinity of China to curb the spread of communism, he set an example and financial strength by accumulating wealth and technology in countries such as Japan, South Korea, Taiwan, Hong Kong, Thailand and Singapore, being a lesson in economics easily accessible to the Chinese people, and the US-China economic rapprochement of 1970, in which the United States sought to break the communist bloc created by the USSR, actually led to the beginning of China's economic growth, being the third great step towards Asian world domination, all created by the West (after the Second World War, that ended the dominant power of Europe on Earth and after the US decision to invest and bring technology to Japan and Asian tigers). Also, the establishment of the O.P.E.C. with the support of the USSR that led to the provocation of the hydrocarbon crisis in the western world, and billions of petrodollars quickly invaded and developed the oil-exporting states of the Persian Gulf, brought a lesson of economy and financial power in the vicinity of India, which along with the former English colonies the same as and she: Singapore, Australia and South Africa (which are part of the Commonwealth, under British rule, then a still strong world organization), created the economic booms in the Indian Ocean.

The economic decline of the USSR, which began in 1980 and ended with its dismemberment and the created world, a decade later, gives China a chance to accelerate. It is beginning to replace the former global power pole previously held by Russia. Until then, China had an economic power equal to India of 180,000 US dollars nominal GDP, but with a population of 300 million people more numerous, which means that only 40 years ago, India and China were economically equal, and a India was living much better, from this moment starting a slight 
competition that accelerates after the year 2000, and by 2020 China has been reached demographic meanwhile by India, manages to be 5 times stronger economically, everything being achieved only in the last 4 decades, and especially in the last two (Frank, 1998; Kennedy, 2017). China's unique opportunity has not been passed on to its southern neighbor, as India is surrounded by poor countries and far from the world's major economic centers.

After the unexpected gain received by China in the 1970s (economic rapprochement with the United States) and 1990 (the decline of the USSR and satellite states) due world changes, the year 1997 and the onset of the economic crisis kneeling Asian economic dragons and tigers, crisis what he directed in the face of small states from East and Southeast Asia to the demographic-civilizational colossus that had been waiting for its chance for over 3-4 centuries. With the decline of communism, the role of the states in the "sanitary cordon" created by the West around the USSR and China was useless, and the money withdrawn by investors, especially Americans, took the path of Eastern Europe and China, in to the detriment of already developed countries, where wages had risen too much and their products competed in the Western market for domestic finished products. As some of these states, with all their financial strength and access to technology, have turned their attention to China more quickly, they have overcome the crisis more easily (see South Korea, Taiwan, Singapore), while Japan with its historical pride remained attached to the West, without recovering economically for the next two and a half decades. Also, the territorial return of the rich colonies of Macao and Hong Kong to China led, in addition to the first major China-Asia-Pacific economic ties, to the creation of the debut of the most dynamic world center called East and Southeast Asia.

Table 1. The economic evolution of the world between 1980 and 2060, in trillions of dollars (Gross Domestic Product nominal)

Source: author estimates and data processed by: Ayres, 2017; Khanna, 2019; Reilly, 2011; Findlay and O'Rourke, 2009; Pomeranz, 2009

\begin{tabular}{|c|c|c|c|c|c|c|}
\hline & $\begin{array}{c}1980 \\
\text { (Trillion US } \\
\text { dollars) }\end{array}$ & 1990 & 2000 & 2018 & $\begin{array}{c}\text { Estimate } \\
2030\end{array}$ & $\begin{array}{c}\text { Estimate } \\
2060\end{array}$ \\
\hline $\begin{array}{c}\text { United } \\
\text { States of } \\
\text { America }\end{array}$ & 2,700 & 5,700 & 10,000 & 20,000 & $\begin{array}{c}26,000- \\
33,000\end{array}$ & $\begin{array}{c}50,000- \\
70,000\end{array}$ \\
\hline Russia & $\begin{array}{c}1,200 \\
\text { (U.R.S.S.) }\end{array}$ & $\begin{array}{c}2,700 \\
\text { (U.R.S.S.) }\end{array}$ & 0,300 & 1,700 & $2,500-3,000$ & $5,000-7,000$ \\
\hline $\begin{array}{c}\text { European } \\
\text { Union }\end{array}$ & $\begin{array}{c}\text { 3,000 } \\
\text { UE-9 state }\end{array}$ & $\begin{array}{c}\text { U,400 } \\
\text { UE-12 }\end{array}$ & $\begin{array}{c}8,500 \\
\text { UE-15 }\end{array}$ & $\begin{array}{c}19,000 \\
\text { UE- } 28\end{array}$ & $\begin{array}{c}23,000- \\
30,000\end{array}$ & $\begin{array}{c}40,000- \\
60,000\end{array}$ \\
\hline Japan & 1,000 & 3,000 & 5,000 & 5,000 & $6,000-7,000$ & $\begin{array}{c}9,000- \\
13,000\end{array}$ \\
\hline China & 0,180 & 0,400 & 1,200 & 14,000 & $\begin{array}{c}28,000- \\
35,000\end{array}$ & $\begin{array}{c}100,000- \\
150,000\end{array}$ \\
\hline India & 0,180 & 0,300 & 0,500 & 3,000 & $7,000-10,000$ & $\begin{array}{c}40,000- \\
90,000\end{array}$ \\
\hline World & 11,000 & 22,000 & 33,000 & 87,000 & $\begin{array}{c}140,000- \\
170,000\end{array}$ & $\begin{array}{c}320,000- \\
530,000\end{array}$ \\
\hline
\end{tabular}

India, less fortunate during this period, it was increasingly outdated economic of China, the nominal GDP ratio between the two ranging from US \$180 billion each in 1980 to $\$ 400$ billion in China and 300 billion in India in 1990, and China will overtake India in 2000 when it reaches 1,200 billions compared to US $\$$ 
500 billion as much as the Indian economy did, a decade in which the Chinese economy tripled (Allen, 2011; Lynch, 2009).

At the level of 2000, it debuted economically in the 21 st century still in low places, China being on the 6th place after the USA, Japan, Germany, Great Britain and France and similar to Italy (which had less than $5 \%$ of its population), while India it ranks only 13th in the world and is surpassed by: Canada, Brazil, Mexico, Spain and South Korea, being almost equal to Australia which had less than $2 \%$ of its population. The small country of Japan had reached an economic output that exceeded 3 times the economic power of Chindiei (China and India), and all 11 cumulatively states that economically exceeded India (except China) had the same population as its own (www.mtholyoke.edu; King, 2016).

The economic decline that strikes in 1997: Japan, South Korea, Taiwan, Thailand, the Philippines, Indonesia or Vietnam, make China seem much stronger, while the events of September 11, 2001 in New York trigger the NATO war in the Persian Gulf and its proximity (Afghanistan, Iraq, economic problems in: Iran, Pakistan, Saudi Arabia and Syria) that bring India to the forefront of the Indian Ocean states, being after gaining independence and the demographic decline of the Western world, the third biggest opportunity for the giant south. Russia's economic difficulties in the first decade after the break-up of the USSR, along with the economic downturn in East and South-East Asia and the wars in the OPEC states after 11 September 2001, which had become the most developed states in the areas in addition to those in the Persian Gulf, and Algeria and Libya in North Africa, Gabon and Nigeria in Central Africa or Venezuela on the South American continent, all this comes with the onset of the 1998-2002 economic crisis that affected South America (Argentina declining economically by almost $30 \%$, followed by a long period of stagnation).

All this time, the annual economic growth of $4-8 \%$ in India and $9-14 \%$ in China, along with the decline of most emerging countries, have made the two demographic megalodons - the center of the global economic boom, creating the term "Chindia" coined by Indian MP Jairam Ramesh, which described the great magnet of planetary wealth (Ramesh and Talboot, 2006).

In the new decade of Asian prosperity, the two countries become the rulers of the continent on which is, by 2010 China's economy will reach 6 trillion US dollars nominal GDP (gaining momentum in Western markets even with the help of globalization supported by rich states) and exceeds Japan on the continent becomes the second world power after the US, while India with 1.7 trillion US dollars rises to 9th place in the world, becoming the third power on the continent. In 2009, India and China set up the first joint project called the BRICs, bringing together Russia, Brazil and South Africa (received in 2010) into the world's most dynamic economic alliance, being tacit an understanding of the new emerging world powers to gain status in front of his old rivals coagulated around the North Atlantic center (USA and European Union). The crisis that began in 2008 affected the near periphery of the Western world, bringing great economic losses especially to Europe (except Poland and Slovakia, all states declining economically) which has been struggling for decades with demographic decline and population aging, the European Union after this episode one step to split. The struggle to get Greece out of the crisis and the problems registered in the east (Romania, Hungary, Bulgaria) and south (Italy, Spain, Portugal) of the union, led to its economic outrunning for the first time by the USA, in the following years. In general, the states that did not register an economic decline were in Asia and its economic extension worldwide, throughout Africa and 
South America (Brazil, Peru), decreasing in states involved in Western economic life at that time: Europe, USA, Russia, Japan, Argentina or the United Arab Emirates.

After the end of the economic crisis, also India and China with average economic growth that recorded annual values of over 7\% between 2013 and 2019, leading the top of the great powers, while Mexico grew by only $2.4 \%$, USA, UK, Canada or Spain by $2 \%$, Germany by $1.7 \%$, France and Japan by $1.2 \%$, Russia by $0.4 \%$ and Brazil had economic decline. The financial crisis that has destabilized the West and boosted the Asian economy has given a new impetus to China, which is now five times stronger than India, reaching 14.1 trillion US dollars in nominal GDP, being closer to surpassing the USA (which has 21.4 trillion, but with a slow economic growth), and India has grown to 2.9 trillion, surpassing in the years 20182019 Great Britain or France holding 2.8 and 2.7 trillion respectively.

When it comes to the power of money held (GDP at Purchasing Power Parity), China with 27.3 trillion dollars already surpasses the US with 21.4 trillion, and India is the 3rd largest world power with 10.5 trillion, over Japan by 5.7 trillion or Germany by 4.4 trillion, but lower than the EU with a PPP GDP of US \$ 18.3 trillion. Basically, Chindia already has a real financial power (GDP PPP) of 39.7 trillion at the beginning of 2020, perfectly equal to the North Atlantic power, following that at the end of the economic crisis that appeared at the end of 2019 and accentuated by the new global epidemic (COVID -19) which will probably have a maximum time of 24 months, after which the two Asian powers will surpass the economy of the old world center of force by the real economic value.

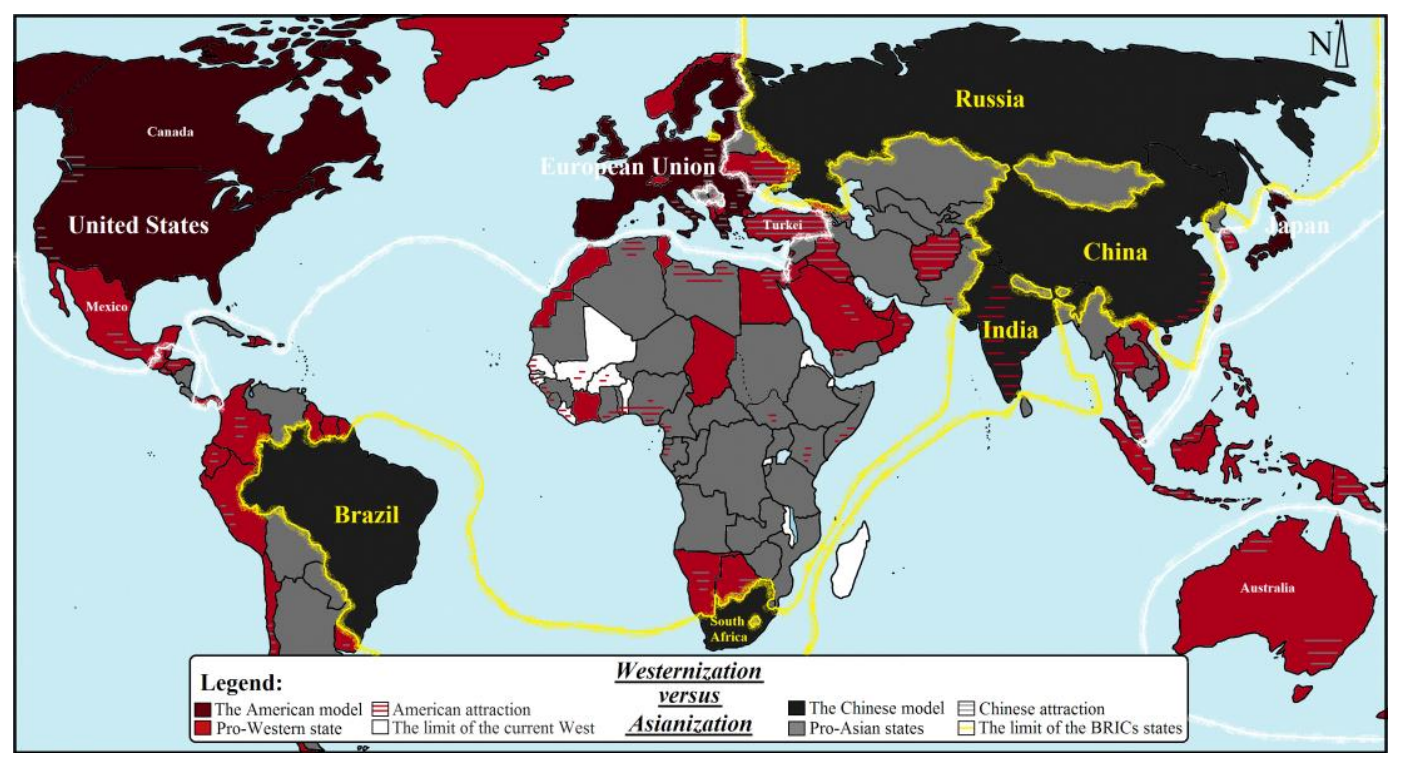

Figura 4. Westernization (US-led) versus Asianization (China-dominated) at the dawn of the 21 st century, between 2005-2030

Sources: author's assessments and data processed after: Carmody, 2013; Maesto, 2019; Favari, 2014; Sawandji, 2018; Zakaria, 2009; Vlad et al., 2010; Suciu et al., 2010; Carvalho and Dughin, 2016; Ionescu, 2005

PRESENT AND NEW BEGINNINGS. PREPARING FOR THE $21^{\text {ST }}$ CENTURY China's economic advance over India is colossal, even though both countries have the same population. But in recent years, India has also entered into increasingly fierce competition with other world economic powers. If we exclude 
from the economic and geographical statistics: USA, China and the European Union, India dominates most of the basic rankings, far ahead: Japan, Russia, Brazil or Indonesia. If we exclude only China, India seems compared to the USA and the EU, which represented China compared to them in 2005. A light list of the most important world productions, highlights the Chinese colossus but also the momentum taken by India in several sectors. China will own as many $\mathrm{km}$ of highways $(149,000 \mathrm{~km}$ in 2019 , compared to $16,000 \mathrm{~km}$ in 2000$)$ as the USA $(96,000 \mathrm{~km})$ and the European Union $(84,000 \mathrm{~km})$ together. Of the top 10 seaports in the world by tonnage of goods, China owns 7 of them while the European Union owns the port of Rotterdam, and for the next 10, 7 are also from China, appearing the first port for the US. Of the top 10 airports in the world after passenger traffic, China has two seats with airports: Beijing ranks second with 100 million passengers and Shanghai ranks 6th with 76 million, while the United States occupies four positions, Japan one position, the Sea Britain one position, France one position and the United Arab Emirates another place, with the next ten positions, the USA, China and the European Union occupying two places each, and India appears for the first time in this ranking with Delhi airport with 68 million passengers, ranking 17th. Worldwide electricity production in 2019 amounted to 27,600 TWh. Of these, China (10,800 TWh from just 1,300 TWh in 2000) produces as much as the US (5,900 TWh), India (2,500 TWh) and Russia $(1,100 \mathrm{TWh})$ together and three times as much as the European Union $(3,400$ TWh) (Neguț et al., 2009, 75-92; Canrong, 2020). China produces 2.5 billion metric tons of cement per year out of a global total of 4.2 billion metric tons ( 600 million metric tons in 2000, out of a total of 1.6 billion metric tons worldwide), which means more than half of world production and eight times more than India's production (320 million metric tons) which ranks second or 28 times the US production (89 million metric tons) which ranks fourth in the world in cement production, which Vietnam ranks third with 95 million metric tons, while European Union production fell from 267 million metric tons in 2006 to $10 \%$ of world production, to less than 130 metric tons million tons (Anton and Peneș, 2008, 61).

Also, China's steel production of 996 million metric tons in 2019, exceeds half of world production, followed by far the powers: the European Union with 150 million tons, India with 111 million tons, Japan with 99 million tons, The United States with 88 million tons and Russia with 71 million tons, China consuming more cement and steel in any three years after 2010, compared to the consumption of the United States throughout the twentieth century. Car production of 92 million units for 2019 is also dominated by China, which produced 26 million, and India manufactured 4.5 million, while the European Union and the United States had production of 17,8 and 11 million respectively, followed by: Japan with 9.7 million, South Korea and Mexico with 4.0 million each, Brazil with 3 million and Thailand, Canada and Russia with about 2 million each (Neguț et al., 2009, 103-112, 139-144; Ramge et al., 2018).

Oil consumption is still dominated by the US, which consumes 19.4 million barrels per day in 2019, and the European Union by 15 million barrels, followed by China with 14 and India with 5.2 million. In contrast, China and India dominate the coal consumption market with 4,320 and 967 mega tons, ie $62 \%$ of world production, followed by the USA and the European Union with 720 Mt. every. Owning the most extensive and productive agricultural land on Earth, China and India lead to the gross value of agricultural production at 2019 prices, with $1,200,000.0$ and $365,000.0$ million US dollars, respectively, followed by the 
European Union with 350,000.0 and the USA with 230,000.0, being followed: Brazil with 167,000.0, Indonesia 135,000.0, Japan 91,000.0, Russia and Turkey with 70,000.0 million US dollars each, while for cereal production, China and India occupies the first and third place with 620 and 310 million tons respectively, the USA and the European Union being on the second and fourth places with 460 million and 300 million tons each, the world heavyweights being followed at a distance by: Russia with 130 million, Brazil 120 million, Indonesia 110 million and Argentina, Ukraine or Canada with 76, 60 and 56 million tonnes respectively (Neguț et al., 2009, p. 211-215; Roberts, 2008).

China's rapid economic evolution finds few comparisons in history, and can be likened to the evolution of Hitler's Germany before World War II, or the evolution of Japan's economy in the second half of the twentieth century. China has become a trade alternative for anti-Western states similar to the USSR in the past, with more and more countries holding more than $50 \%$ of the trade value with this superpower. In 2019, among the largest trading powers in terms of export value, China is at the top with 2.6 trillion US dollars, followed by the United States with 2.5 trillion, the European Union 2.3 trillion $(7.6$ trillion if we add exports between the states of the Union) and Japan by 0.9 trillion, the other powers being far behind: South Korea 0.6, Canada, India, Mexico or Russia by 0.5 trillion each) (Maçães, 2018; Burrows, 2016; Dobrescu, 2016).

From these statistics we understand the value of great power gained by China in the last two decades, but also the spectacular growth of India, which is lacking in most rankings ten or twenty years ago. The two banks created with the major influence of China (Asian Investment Infrastructure Bank AIIB established between 2013 and 2016 based in Beijing and the New Development Bank NDB formed by the BRICs between 2014-2015, based in Shanghai) (Goh, 2016; King, 2016) with an increasing influence on European states, but also the management of the current epidemiological crisis of coronavirus as a result of which China (along with Russia which is its right hand in Eastern Europe), massive investments in recent years and the implementation of the axis "Silks Road "make it an ally that promises to pull the Old Continent out of the lethargy that has held it in place for two decades. The glow for India, in coalition with Japan, Australia and the United States, is already beginning to be expected, with investment expected to make its way to its economy. Thus the economically weak states put their hope in investments coming from China, and those in control of the economic situation go alone to India, this opening resembling the year 1970, when China was taken from its ally USSR, so India is drawn from anti-Western coalition BRICs. In fact, these days the foundations are being laid for the future colossal Indian power and the global economic split into two major blocs, both led from Asia.

China assigns its "Inland Pacific Lake" in which the US-India coalition strategically hung by: Japan, Vietnam and maybe Russia in the future, will try hard to head to India, while India assigns its "Indian Inland Lake" in which China may, along with the European Union and clinging to: Pakistan, Bangladesh, Iran and Sri Lanka try to curb Indian influence in these waters (as Cuba or Nicaragua near the US go relational to China and Taiwan or Vietnam near China go to the US).

Continuing the current global economic trajectory, in which Asia will accumulate more and more wealth throughout the $21^{\text {st }}$ century, the Chinese economy is expected to come in first place (GDP Nomina) equaling the powers of the US and the European Union together, around 2055, and India could ranks 
second, slightly ahead of the EU and equal to the US, while the end of this century it is possible to classify this ancient Asian power in first place in the world, surpassing China with its population getting older.

\section{THE ASIAN CENTURY. ASSIGNMENTS OF CHANCES}

Each of the two ancient world civilizations, China and India, currently account for $18 \%$ of the world's population, followed by the United States with 4.2\%, Indonesia with 3.5\% and Pakistan, Brazil and Nigeria with $2.7 \%$ each. That is, the next 5 states fail to gather the same population as one of the two world demographic powers, compared to India, this trend is found and in the next 3 decades. There are a multitude of elements that give economic priority to one or the other power for the century that has just begun, except for the dramatic case when, under the burden of ethnic (especially India) or economic (China) differences within these countries, it will lead to dismemberment, in the territories smaller and less compatible globally, being among the few unforeseen situations that will make them not represent major world forces in the future.

Among the main economic and demographic advantages of China could be considered: the economic advance over India, which it has exceeded 5 times; a working-age population, in which the population explosion no longer exists, reducing the risk of further overpopulation; this country with a large number of companies in the world, specializing in workers, hardworking and very determined; the majority of the population in the eastern area being from the inn and Taoist religion population with slight tendencies towards Christianity. But the disadvantages are also commensurate; the Chinese economy being a planned and majority one with the involvement of the state, having a certain rejection on the western market that treats it suspiciously; the cessation of population growth sets a bleak future in which the population will age and shrink rapidly (China will have 400-600 million fewer people by 2100, when it will be overtaken by Nigeria); population of the provinces surrounding central China: Heilongjiang, Jilin and Liaoning (populated by Manchurians), Inner Mongolia (populated by Mongols), Xinjiang (populated by Uighur Turks), Tibet and Qinghai (populated by Tibetans) or Yunnan and southern Guizhou (populated by with various ethnic minorities) tend to depend on seeking external allies; the difference in development between the economically advanced coast and the interior of the country make this colossus a centrifugal internal power.

Among the economic and demographic advantages of India are: healthy growing Indian power with individual capitalist accent; being a fairly prosperous power and an oasis of democracy and stability compared to the states that have access to the Indian Ocean; the largest democracy in the world with increasingly visible affinities of Western economies towards it, identifying to some extent with it; with a young and growing population; increasingly specialized workforce with Western aid; knowledge of English and Hindi which is the most widespread but also languages such as: Urdu, Punjab or Bengali which are also spoken in neighboring Pakistan and Bangladesh, while Tamil is also spoken in Sri Lanka, in this sense having a certain brotherhood linguistics fraternity with the surrounding states, while the Hindu religion is considered calming by promoting nonviolence. Disadvantages include: lack of rules in the economy and the permanent risk of bankruptcy for companies; areas of poverty with densities of over $1000 \mathrm{~km}^{2}$ accumulated in the underdeveloped interior of the Ganges Plain; continuous population growth; the multitude of ethnic groups easily manipulated from the 
outside to move towards territorial independence and the ravages of the IndoIslamist war present in most parts of the country.

Among the geographical advantages, both states have sufficient water resources with areas of excess but also deficit, easily adjustable by anthropogenic interventions, but China has a temperate climate (which has proven in past centuries to be a priority for development, in this climate there are: USA and Canada, Europe and Russia or Japan, and in the south: Argentina, South Australia or South Africa) but affected by hurricanes in the east (similar to Florida, Alabama, Mississippi, Louisiana or Texas in the USA) and in the north reaches the Siberian frost, while India has a tropical climate (being the new similar world development site: Thailand, Singapore, Malaysia, Hong Kong area, Florida area, Texas or California in the USA, Brazil, Panama, Israel, Kuwait, United Arab Emirates or Canary Islands Spanish) being attached in value to the population between the parallels of 300 latitude. It turned out that the products, technology, way of life and manifestation of people copied themselves horizontally (along the parallels), with a trend that occupied the temperate zone, representing the old developed world of which China is part and a trend at the equator, which is beginning to grow economically and demographically, of which India is a part.

The relief limits anthropogenic China to the eastern half, paved with jungles, mountains, desert and frozen land (somewhat similar to US or Russian land), while India has 50\% more arable land, occupying almost the entire country (similar to the territory of the European Union, where most of it is humanizad). Regarding the natural maritime capacity, although China has the advantage of going out to waters with high commercial activity, close to: Japan, South Korea, Taiwan, Singapore, Thailand, Russia and so on, being on the developed route to the USA, precisely this proximity to the great naval powers and the islands surrounding the coast are held captive by external forces, preventing it from becoming a full maritime power (the situation persists following a possible absorption into Taiwan's own territory). Instead, India is like a triangle (or even a rhombus) in which two parts are bathed by the waters of the Indian Ocean and one north crossed by the navigable river Ganges with access to its own territory to the ocean (through the Hooghly arm that detaches from the Ganges and passes through the city of Calcutta before reaching the ocean, thus bypassing the state of Bangladesh).

Perhaps India's greatest maritime advantage and one of the major changes in recent decades is that the population around the Indian Ocean, which was less numerous than the population around the Pacific and Atlantic Oceans in 1950 (760, 908 and respectively 805 million people), has grown to 3,160 million today (surpassing the estimated population around the Pacific at 2,280 million and the Atlantic by 1,920 million), continuing this trend when the population around the Indian Ocean will hold over 40\% of the world's population in 2050 with 4,400 million inhabitants $(2,350$ million around the Pacific and 2,600 around the Atlantic) and $50 \%$ of the world's population by 2100 , with an estimate of between 5,200 and 5,900 million (between 2,100 and 2,500 million around the Pacific and between 3,100 and 3,500 millions around the Atlantic) (Worldometers, 2020; Diaconescu, 2018). Thus, around these waters is expected the largest world trade and the most dynamic area, practically being considered that who will dominate the waters of the Indian Ocean will dominate the Island of the World (Asia, Africa and Europe) and hence the entire planet, being a increasing trade between China, Japan and South-East Asia on the one hand and Europe, the Middle East and 
Africa on the other, this trade passing through the proximity or territory of India (O,Brien, 2010; Diaconescu, 2020).

Seen from the outside, China is seen as a power based on foreign investment and an alternative to the Western market, being a formidable ally against American interests. But through economic expansion and the territorial threat to neighboring states, it has upset the great powers, including: Japan with its islands of Nansei (Ryukyu), the United States with Asia-Pacific alliances, Russia with Siberia (This being populated by tribes related to the population China, while two eastern thirds, increasingly economically attracted to China, have a smaller population than any of the top 20 Chinese urban areas, on an area as large as the US), Vietnam, the Philippines, Malaysia and Indonesia with the islands of Paracel and Spratly from the East China Sea, with an oil-rich subsoil, waters essential to fishing and focused on trade routes vital to the area, which are invaded by China and claimed by other states. Precisely because of this attitude, which has been detected since the European invasion, China has been called the "Roman Empire of Asia", while India, philosophically, with its white, Hindu population, a forbiddance against planetary Islamization, with English and democracy is considered "Asia's Greece", broadly perceived as the future part of the Western world.

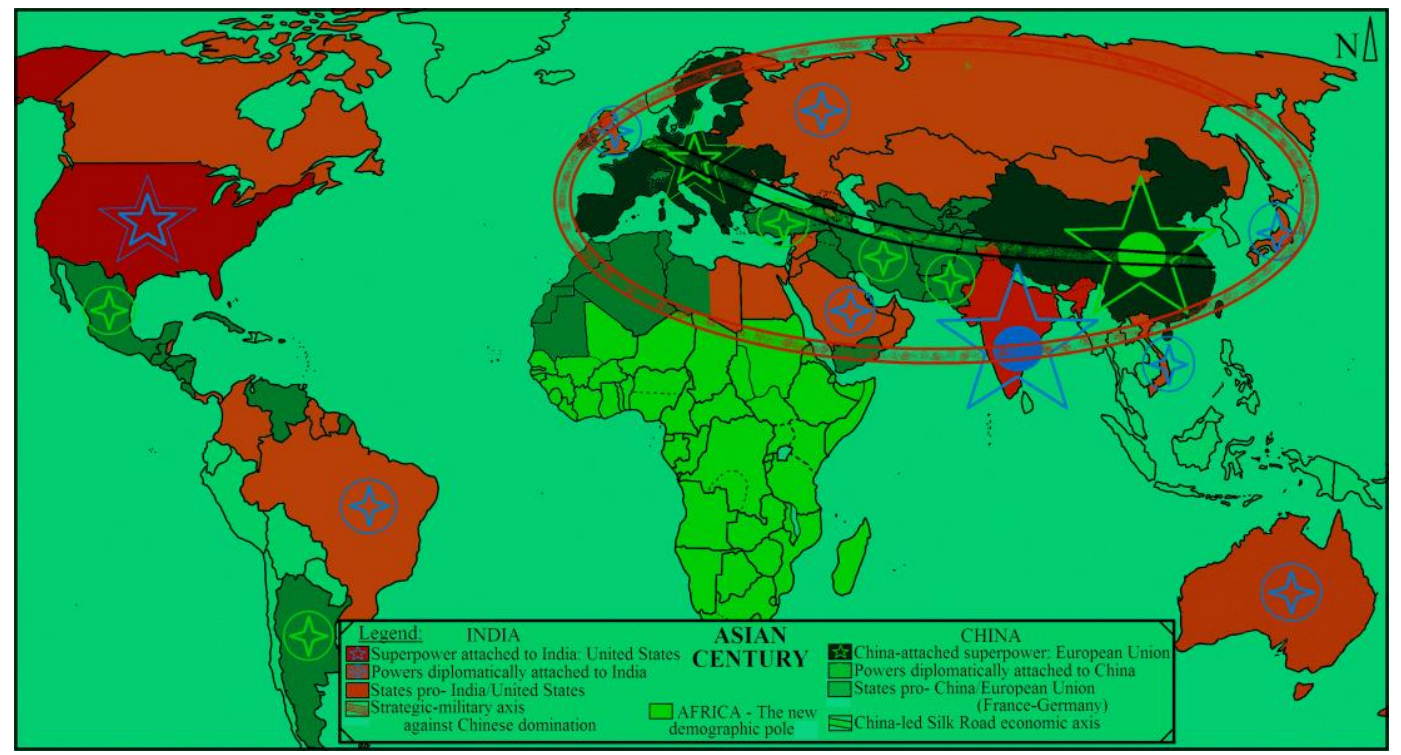

Figure 5. The Asian century between 2040 and 2100. Hegemonic division between India and China, towards the end of the $21^{\text {st }}$ century

Sources: author's predictions and inspiration after the works: Frankopan, 2018; Basten et al., 2013; Lutz, 2008; Lutz \& Samir, 2010; Meinig, 1956; Guillermo, 2015; Hugon, 2015

For the next decades, the European Union is expecting foreign investment that will most likely come from China, while the US and the UK export investments expected by India. Japan, Russia and Vietnam are economically attached to China, but in territorial conflict with it, bringing their investments more and more to India. Australia and Brazil export raw materials to China, but after Chinese economic takeover, try to become more independent by moving to India. 
Mexico is looking for allies in China, Spain and so on, to protect its Spanishspeaking emigrants from the US, where southern states such as: California, Arizona, New Mexico, Texas or Florida that once belonged to Spain or Mexico, will be repopulated mostly with Hispanics (Friedman, 2009). Saudi Arabia, populated by Indians and developed with American technology, remains an ally of the United States and India, but Iran in conflict with it allies with China or Germany in the European Union. Pakistan, in its endless wars with India, expects military aid and Chinese investment, and Turkey is blocked to head south where it meets the US allies and Israeli allies and in the north Russian influence, will move to the IranPakistan-China axis to the east, and in the west it is trying to attach itself to Germany where 5 million Turks live (even if it will maintain its conflicts with Greece and Bulgaria), supporting the Silk Road that will connect China and the European Union on a land route. Egypt will enter into a diplomatic conflict with Turkey for dominating the Arab world but also representing the interests of Arab Islamists in Europe, Turkey remaining the advocate of the non-Arab Islamist population (Turks, Bosnians, Kosovis, Albanians and so on).

Argentina, after the financial conflict with the USA that caused its crisis in 2002 and the territorial conflict with Great Britain for the Falkland Islands (Malvinas), is heading to China and France, Italy or Spain (European Union), but remains friends with Brazil. It is not clear which path Korea will take, which will probably unify, nor will Southeast Asia. Africa, economically and diplomatically allied with Europe in the past, with the US in recent decades and increasingly with China today, will try an attitude of neutrality or even self-assertion (it seems that the burden of Chinese debt is increasingly difficult to pay, unfinished projects or upset for Chinese projects developed in their enemy states, all this will lead Sub-Saharan Africa slightly to India after 2035).

Both India and China need raw materials, fighting on the same sparsely populated and resource-rich territories such as Russia, Australia, African states, Arab states, Latin America and so on, so it is not clear how they will share the riches of the planet. But we know for sure that they will become colossal raw material importing powers, with their economic development, and the old powers such as the: USA, the European Union, Japan, Russia, Great Britain and so on, will fight various new actors. India and China: to reduce their global economy and influence, to develop on an equal footing with each other while maintaining the balance of power, to pit them against each other by destroying each, to take advantage of the investments they export, the growing workforce specialized, of the import market of finished products or raw materials or of investments in the markets of these new world actors. The extent of these actions of the old powers over the new ones is very difficult to decide.

The Himalayas (Tibet), the Indochina Peninsula and the Malaysian archipelago will be the geopolitical confluence dotted with sudden conflicts and buffer states, while Sub-Saharan Africa with its huge population until then (between 2070 and 2100 is expected to have a projected population between 2.5 and 4 billion people, so how many: India, China, the European Union and the USA together), being the new realm of foreign investment (as was China between 1970 and 2030 or India between 2000 and 2060). India with the help of the: USA, Japan, Vietnam, Russia, Great Britain and the Arab states developed from the Persian Gulf gathered in the Gulf Cooperation Council, will rely on the maritime encirclement on the outside of Rimland, while China with the help of the Silk Road that will cross : Pakistan, Iran, Turkey and the European Union, will unite 
the three oceans: Pacific, Indian and Atlantic, crossing the interior of the Heartland. Although Russia remains an economic ally with Germany and China, the infiltration of the Chinese population into sparsely populated Siberia and Beijing's support for the Russian-conquered Tibetan-Mongol-Chinese peoples in the past centuries will make Russia a tacit ally of India and perhaps Japan and the enlargement of the European Union to Eastern Europe, an expansion orchestrated by Berlin, will lead to a strategic rapprochement between Russia and Great Britain or the USA, avoiding the emergence of a great power in Central and Eastern Europe, which would be hostile to them.

\section{CONCLUSIONS}

Chindia has owned for over 10 centuries, over $33 \%$ of the world's population, and along with: Japan, Korea, Vietnam, Indonesia, Philippines, Pakistan, Bangladesh and in general Southeast Asia expanded, is the world's demographic center with $52 \%$ of the Earth's population on only $12 \%$ of its land area (Only Southeast Asia has a population almost as much as Europe, and Japan with Pakistan and Bangladesh have as much as the entire population of North America). And their historical value is just as overwhelming, here being the great Indian and Chinese civilizations that formed the basis of the civilized world. Like so many cases throughout history, the fact that they deserved a privileged position at the table of the great world economic powers did not mean that they received this place, without work, strategy, national will and a drop of chance, the two world demographic megalodons they became colonies, faced long wars and famine in the most severe ways, diyng at least 60-80 million malnourished people in the twentieth century alone. But their total independence after 1950 and the wars between Europeans that left gaps in world influence gave the two a chance to assert themselves. The tiring cold war between the USSR and the communist bloc states on the one hand and the US with its allies on the other, but also the subsequent accusations of the European Union and Japan on the US of world economic domination, or China's accusation of total hegemony of the communist world to the USSR, they created gaps, leaving the chance of the most bizarre rapprochements, when the USSR came closer economically to India and the USA to China, even if they were part of different ideological worlds.

The economic crises that have affected the major regions of the world, have given even more chances to assert themselves to the two Asian actors, and the demographic decline more pronounced in: USA, Japan, Russia, Brazil or the European Union (between 2000 and 2020 the population increased by 1.8 billion people, while in Europe the population stagnated at 0.7 billion), affecting all developed or second world countries, this decline leading to investments towards the over 1.30 billion workforce as far as Chindia is concerned, out of 3.40 billion workers worldwide (the European Union has only 0.24 billion, the US 0.16 billion, Russia or Japan being far behind by 0.07 and 0.06 billion respectively). Russia-US, Japan-US or EU-US economic conflicts have become irrelevant, with China winning all, and the current US-China conflict over the next two decades will bring India to victory.

\section{REFERENCES}

Allen, R. C. (2011). Global economic history: a very short introduction (Vol. 282). Oxford University Press. Anton, A. (trans.), Peneș, D. (trans.), (2008). Atlasul lumii: enciclopedia geografică a familiei: Vol. I: Geografica (The Atlas of the World: Geographical Encyclopedia of them Family: Vol. I: 
Geografica), Editura Erc Press, București.

Attili, J. (2016). Scurtă istorie a viitorului (Brief history of the future), Polirom Publishing House, Bucharest, Romania.

Ayres, A. (2017). Our time has come: How India is making its place in the world. Oxford University Press.

Basten, S., Lutz, W., \& Scherbov, S. (2013). Very long range global population scenarios to 2300 and the implications of sustained low fertility. Demographic Research, 28, 1145-1166.

Baten, J. (Ed.). (2016). A history of the global economy. Cambridge University Press.

Burrows, M. (2017). Viitorul declasificat. Megatendintele care ne-ar putea distruge lumea. Grup Editorial Litera. (The declassified future. Megatrends that could destroy our world), Litera Publishing House, Bucharest, Romania.

Canrong, J. (2020). China. Responsabilitatea unei mari puteri (China. The responsibility of a great power), Corint Books Publishing House, Bucharest, Romania.

Carmody, D. P. (2013). The rise of the BRICS in Africa: The geopolitics of South-South relations. Zed Books Ltd..

Carvalho, O., Dughin, A. (2016). Statele Unite și Noua Ordine Mondială (The United States and the New World Order), Humanitas Publishing House, Bucharest, Romania.

Diaconescu, L. (2018). Geopolitics of the Oceans: The Demographic Influence in the Separation of Powers. Revista Română de Geografie Politică, 20(2), 75-85.

Diaconescu, L. (2018). Geopolitics of the Oceans: The Demographic Influence in the Separation of Powers. Revista Română de Geografie Politică, 20(2), 75-85.

Dobrescu, P. (2016). Crizele de după criză. O lume fără busolă şi fără hegemon (Crises after the crisis. A world without a compass and without a hegemon). Grup Editorial Litera.

Favari, S. (2014). Scacchiera africana: confronto di strategie tra Cina e Stati Uniti nel continente nero. Fuoco edizioni.

Findlay, R., \& O'rourke, K. H. (2009). Power and plenty: trade, war, and the world economy in the second millennium (Vol. 30). Princeton University Press.

Frank, A. G. (1998). ReOrient: Global economy in the Asian age. Univ of California Press.

Frankopan, P. (2019). The new silk roads: The present and future of the world. Knopf.

Friedman, G. (2009). Următorii 100 de ani: previziuni pentru secolul XXI (The next 100 years: forecasts for the 21st century), Litera Publishing House, Bucharest, Romania.

Gâștescu, P., Murărescu, O., Bretcan, P. (2004). Oceanografie (Oceanography), Transversal Publishing House, Bucharest, Romania.

Goh, E. (Ed.). (2016). Rising China's influence in developing Asia. Oxford University Press.

Gray, C. S. (1977). Geopolitics of the nuclear era: heartland, rimlands, and the technological revolution. Hudson Inst., NY.

Grumaz, A. (2013). Al Treilea Război Mondial (World War III), Rao Publishing House, Bucharest, Romania.

Guillermo, M.J. (2015). Geopolitica de África, Editorial Dunken, Buenos Aires, Argentina.

Herman, G. V., \& Grama, V. (2018). Geographical aspects of space-time evolution of independent states. Revista Românā de Geografie Politică, 20(2), 49-56.

Hobson, J. M., \& Hobson, J. M. (2004). The Eastern origins of Western civilisation. Cambridge university press.

Hugon, P, (2015). Geopolitica de África, Escolar Editora, Lisbon, Portuga.

Huntington, S.P. (2018). Ciocnirea civilizațiilor și refacerea ordinii mondiale (The clash of civilizations and the restoration of world order), Litera Publishing House, Bucharest, Romania.

Ianoș, I., Iacob, G. (1989). Câmpiile Terrei (The plains of the Earth), Albatros Publishing House, Bucharest, Romania.

Ilieș, A. (2006). Elemente de geografie politică: Spațiul european (Elements of Politica Geography: European Space), Universitatea din Oradea, Facultatea de Geografie-Istorie, Departamentul de Geografie, Turism și Amenajarea teritoriului, Oradea, Romania.

Ionescu, M.E. (2005). Sfidarea Westphaliei: relații internaționale: 1996-2004 (Defying Westphalia: International Relations: 1996-2004), Politeia-SNSPA Publishing House, Bucharest, Romania.

Kaplan, R.D. (2015). Răzbunarea geografiei. Ce ne spune harta despre conflictele viitoare și lupta impotriva destinului (Revenge of geography. What the map tells us about future conflicts and the fight against destiny), Litera Publishing House, Bucharest, Romania.

Kennedy, P. (2017). The Rise and Fall of the Great Powers: Economic Change and Military Conflict from 1500-2000, William Collins Publishing House, New York, U.S.A.

Khanna, P. (2019). The future is Asian: Global order in the twenty-first century. Hachette UK.

King, M. (2016). The end of alchemy: Money, banking, and the future of the global economy. WW Norton \& Company.

Lutz, W. (2008). Exploratory Extension of IIASA's World Population Projections: Scenarios to 2300, International Institute for Applied Systems Analysis, Austria.

Lutz, W., \& KC, S. (2010). Dimensions of global population projections: what do we know about 
future population trends and structures?. Philosophical Transactions of the Royal Society B: Biological Sciences, 365(1554), 2779-2791.

Lynch, M. (2009). China modernă (Modern China), Niculescu Publishing House, Bucharest, Romania. Maçães, B. (2018). The dawn of Eurasia: On the trail of the new world order. Yale University Press.

Maesto, R. (2019). La variabile africana. Riserve naturali ed equilibrio geopolitico del pianeta, Editore EGEA, Milano, Italia.

Marshall, T. (2019). Prizonierii geografiei. Zece hărți care ûți spun tot ce trebuie să ști despre politica globală (Prisoners of geography. Ten maps that tell you everything you need to know about global politics), Litera Publishing House, Bucharest, Romania.

Mâșu, S. (2014). Puterea economică în istoria lumii: 1. De la Marele Rift preistoric la Marele Război din 1914 (Economic power in world history: 1. From the prehistoric Great Rift to the Great War since 1914), RAO Publishing House, Bucharest, Romania.

McGregor, R. (2017). Asia's reckoning: The struggle for Global dominance. Penguin UK.

Meinig, D. W. (1956). Heartland and rimland in Eurasian history. Western Political Quarterly, 9(3), 553-569.

Navarro, P. (2011). China - Războaiele care vor veni: unde vor fi duse și cum pot fi câștigate (China The wars to come: where they will be fought and how they can be won), Niculescu Publishing House, Bucharest, Romania.

Neguț, S., Vlăsceanu, G., Bran, F., Popescu, C., Vlad, L.B., Neacșu, C.M. (2009). Geografie economică mondială (Geography world economy), Meteor Press Publishing House, Bucharest, Romania.

Nguyen, E. (2017). Géopolitique de l'Afrique, Editeur Studyrama Eds, Paris, France.

O,Brien, M.D. (2010). The Island of the World, Ignatius Press, USA.

Parthasarathi, P. (2011). Why Europe grew rich and Asia did not, Cambridge University Press, UK.

Pomeranz, K. (2009). The great divergence: China, Europe, and the making of the modern World economy, Princeton University Press, USA.

Popa, N. (2004). Geografia continentelor. Asia. Caracterizare geografică generală (Geography of continents. Asia. General geographical characterization), Universității de Vest Publishing House, Timișoara, Romania.

Ramesh, J., Talboot, S. (2006). Making Sense of Chindia: Reflections on China and India, India Research Press, New Delhi, India.

Ramge, T., Schwochow, J., Garcia-Landa, A. (2018). The Global Economy, The Experiment Publisher, New York, USA.

Reilly, J. (2011). Strong Society, Smart State: The rise of public opinion in China's Japan policy, Contemporany Asia in the World, Columbia University Press, New York, U.S.A.

Roberts, A. (2013). Furtuna războiului (The storm of war), Litera Publishing House, Bucharest, Romania.

Roberts, P. (2008). Sfârșitul petrolului (The end of oil), Litera Internațioanal Publishing House, Bucharest, Romania.

Roberts, P. (2009). Sfârșitul hranei (The end of food), Litera Internațional Publishing House, Bucharest, Romania.

Roy, O. (2001). Noua Asie Centrală sau Fabricarea națiunilor (New Central Asia or the Manufacture of Nations), Dacia Publishing House, Cluj-Napoca, Romania.

Sawandji, J.J.A. (2018). Globalizzazione e conflitti. Un itinerario geopolitico sull'Africa subsahariana, Editore Aracne, Rome, Italy.

Săgeată, R. (2008), Geopolitică, Universității "Lucian Blaga” Publishing House, Sibiu, Romania.

Stuart-Fox, M. (2003). A short history of China and Southeast Asia: tribute, trade and influence, Allen $\&$ Unwin Publishing House, Australia.

Suciu, F.B., Caunic, I., Muntele, I. (2010). Euro-Atlantic democracy confronting a strategic challenge. Revista Română de Geografie Politică Year XII, (2), 285-296.

Toffler, A., Toffler, H. (1995). Război și Anti-Război: supraviețuirea în zorii secolului XXI (War and AntiWar: Survival at the Dawn of the 21st Century), Antet Publishing House, Bucharest, Romania.

Vlad, L. B., Josan, A., \& Vlasceanu, G. (2010). Active geo-strategic players, geopolitical pivots and the changing balance of power in Eurasia. Revista Română de Geografie Politică, 12(1), 116-125.

Zakaria, F. (2009). Lumea postamericană (The post-American world), Polirom Publishing House, Iași, Romania.

*** WORLDOMETERS, real time world statistics: www.worldometers.info, last accessed, May, 2021 https://www.mtholyoke.edu/acad/intrel/ipe/2000-09GDP.htm

Submitted:

February 18, 2021
Revised:

Mai 25, 2021
Accepted and published online: June 06, 2021 